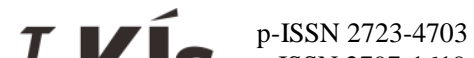

\section{The Implementation of Ethical Journalism Based on Teleological Approach in TVRI Jakarta}

\author{
${ }^{1}$ Fachry Dwito Akbar, ${ }^{2}$ Muhammad Rizky Febrian, ${ }^{3}$ Prima Widiastuti, \\ ${ }^{1}$ Universitas Islam Negeri Jakarta \\ 1 fachrydwitoa@gmail.com, ${ }^{2}$ muhammadfebrian12345@gmail.com, \\ 3 prima.widiastuti08@gmail.com
}

\begin{abstract}
ABSTRAK
Artikel ini bertujuan untuk mengetahui bagaimana pendekatan teleologis digunakan oleh para jurnalis yang tentunya harus sesuai dengan kode etik jurnalistik di Stasiun TV TVRI Jakarta. Dan dalam bidang jurnalistik apakah kode etik jurnalistik itu penting?. Metode penelitian ini menggunakan metode kualitatif dan menggunakan instrumen wawancara dengan dua orang narasumber dari stasiun TVRI, Jakarta. Hasil yang diperoleh adalah pendekatan teleologis ini seringkali digunakan oleh para jurnalis di TVRI Jakarta dalam menjalankan tugasnya, dan tentu penggunaannya harus sesuai dengan kode etik jurnalistik.
\end{abstract}

\section{Kata Kunci: Kode Etik, Jurnalistik, Pendekatan Teleologi, Wawancara}

\section{ABSTRACT}

The article aims to find out how the teleological approach is used by journalists who should, of course, adhere to the journalistic ethics code at TVRI Jakarta. And in the field of journalism is the ethical code of journalism is important?. This research method employs qualitative methods and uses interview instruments with two sources from the TVRI station in Jakarta. The result is that this teleological approach is often used by journalists at TVRI Jakarta in carrying out its duties, and of course, its use should be consistent with a journalistic code of ethics.

Keyword : Code of Ethics, Journalism, Teleological approach, Interview

\section{INTRODUCTION}

Ethics is crucial in the field of journalism, especially to journalists. The ethics of journalistic conduct is a parameter for how well the people have extended to their press. Journalistic ethics is not only about ideal values but it can be used as a guideline and professional requirement. An understanding of the ethical code of journalism is inherent in the journalist profession, two things virtually inseparable.

Previous studies associated with this title are among the things that (Babran and Ataherian 2019), which point out that it is a major error in journalistic ethics when journalists cannot properly execute the ethical code of journalism. Since the reformation, ethics in journalism has gone unnoticed. The ethics code does not reduce motion or restrict journalists' credibility, nor does it restrict press freedom, but as its owner and adhere to a code of conduct. Second is (Kryukova et al. 2018) 
state that ethical journalism means taking responsibility for one's job and explaining one's decisions to the public. Third is previous studies related to the code of ethics (Fitri and Adeni 2020) mention that journalistic ethics are essential for online Islamic media reporting, thus affecting the credibility of journalists, media agencies, and communities. And the fourth regarding the implementation of the code of ethics (JCE) in its case of children with the law, (Arifin and Handayani 2020) journalists who are members of the Indonesian Association of journalists and the journalistic alliance of Indonesia have done coverage of the ethical code of journalism, especially those that are related to child questions contrary to the law. Journalists have been created to accept the ground rules of the journalistic code of ethics.

Many other researchers have analyzed how this teleological approach is applied to journalism, and there are also some events of the teleological approach in journalism that seem less appropriate because it does not fit the ethical code of journalism, and teleological approaches that are used according to the journalistic code of ethics that produce ethically ethical and ethical products. The difference between our research and the research we encountered earlier is that our focus is on a journalistic environment on TVRI Jakarta television station.

In the field of journalism, we found some journalists who still have not followed this ethical code of journalism correctly, for example in the news ("Kasus Setya Novanto, Metro TV Tak Toleransi Pelanggar Kode Etik - Metro Tempo.Co" n.d.) "case Setya Novanto, Metro TV does not tolerate code violations" contained by Tempo.co "Metro TV reporter Hilman Mattauch, is accused of hiding Setya Novanto, a suspect in his electronic citizen id (e-id), in his apartment when he disappeared to be picked up by the commission on corruption (KPK) on Wednesday, November 15, 2017" and many other examples of journalistic ethics violations.

Problems in violations of the ethical code of journalism have solutions based on Wiling Barus's ready Theory of Ethics (2010: 235) are the moral and work ethic set up and determined by professional organizations to prevent members of appropriate professional organizations from engaging in practices that endanger professions and society. Freedom of the press is used as a basis for violating the rights of others, hence an ethical code is essential. 


\section{RESEARCH METHODS}

\section{A. Reasearch Methods}

This research method involves qualitative methods. Qualitative research is descriptive and tends to use analysis. Process and meaning are more stressed in qualitative research. Qualitative methods stress more on phenomena observation and more research into the meaning of the phenomenon. Qualitative research and analysis are profoundly affected by the power of words and sentences used. (Basri 2014) therefore, concludes that the focus of qualitative research is on the process and its output. The focus of qualitative research focuses more on human elements, objects, and institutions, and relationships or interactions between those elements, to understand an event, behavior, or phenomenon. In qualitative research, researchers played a key role in planning, carrying out data collections, analyzing, interpreting data, and eventually becoming a research report. The approach he used was the case study approach, which conducted interviews during research.

\section{B. Subjects and Objects of Research}

We have selected some journalists from TVRI Jakarta to help us in this research. They are some experienced journalists who are pretty experts in their field and willing to give us accurate information by answering our questions. Here is the list of journalists from TVRI Jakarta we managed to contact.

\section{Source Person Table}

\begin{tabular}{|l|l|l|}
\hline No. & Source Person Name & Status \\
\hline 1. & Eka Widya & Reporter at TVRI Jakarta \\
\hline 2. & Fathanisa & Reporter at TVRI Jakarta \\
\hline
\end{tabular}

\section{Data collection methods}

The method used in this study is through interviews and documentaries.

\section{Interview}

The interview is a one-on-one conversation. One person acted as an interviewer and another acted as the one being interviewed or the source. The purpose of this interview is to gain knowledge of the subjective significance understood by the source to be interviewed. As for this interview, the TV journalist has a source, and the semi-structured interview of researchers is taking the questionnaire/guide interview into questions that will be asked to the source. The questionnaire will make it easier for researchers to collect data from sources. 


\section{Documentation}

The data-gathering technique with the documenting of it is to collect data using a mobile camera to record conversations with the source.

\section{Data Collection Tools}

1. Questionnaire: used by researchers to interview a subject or a source to avoid interfering with the purpose of research.

2. Recorder/mobile: a researcher USES a screen recorder's phone on his laptop and then records conversations with the source. Researchers have done this to make it easier in the process of data retrieval.

3. Writing tools: stationery and a notebook for recording everything related to the path of research.

\section{Data Analysis Techniques}

The next step is to process and prepare the data for analysis. The move requires transcripts of interviews and questionnaires. The next step is to make a resume from a transcript of the interview, which makes it easier to jump to conclusions.

\section{RESULTS AND DISCUSSION}

According to the interview of both reporter TVRI Jakarta, they know the ethical code of journalistic ethics, which is the basis, the rules and policies agreed upon by the journalistic community or the board of journalism on which the platform is used by journalists while working, it picks up ethical matters that should or should not be done by a journalist, and it has a purpose for a journalist to act within the bounds of the rules and to avoid things that could harm the public. Media regulation is a combination of standards and media ethics necessary to support freedom of expression and the media behavior monitoring process. Media-related regulations focus on the increased professionalism and ethics that are standard for journalists to pursue journalistic work. The professionalism and ethics that are rated in the work of journalism were the cornerstones of forming a mainstream media industry that is recognized as one of the pillars of democracy and community development. Dewan Pers is a society, they also have a role of oversight in the lives of the national press who seek to keep it free from attempts to undermine it (Erawaty and Irwansyah 2019). Four ethical standards are set in the SPJ code, which involves finding the truth and reporting it, minimizing loss, acting independently, being accountable, and transparent. Journalists have to be accurate and fair. Journalists must be honest and brave to collect, report, and interpret information. Ethical journalism treats resources, subjects, colleagues, and members of society as respectable human beings. The highest and foremost obligation of ethical journalism is to serve the public. Ethical journalism means taking 
responsibility for one's job and explaining one's decisions to the public. (Kryukova et al. 2018)

As a journalist, of course, you have to work through the journalist's code. This is because ethics is already part of the world of journalism. Journalists must take care of their day-to-day responsibilities under journalistic ethics. For ethics are "bonds," that can be exercised with a degree of freedom in their actions ("Ethical Journalism - The New York Times" n.d.). Professional and qualified journalists submit to their ethics codes and understanding and competence of the code. Journalists have been referred to as "the fourth branch of government," which means they are community supervisors and must inform the public about a situation they are not intimately or previously aware of. Without ethical journalism practices, we commit social injustice and potentially damage or damage our reputation and that of journalism as a whole. Ethics is the minimum value or moral tradition used to separate truth from error and good from evil. (Katz 2010). Journalistic ethics is a code that journalists abide by. News coverage has a purpose. To achieve that goal, journalists must stick to the professional ethics they understand in news coverage. Journalistic ethics can be defined as an ethically applied ethicist that studies micro issues relating to journalistic behavior as well as macro issues about the behavior of overall media organizations. As members of organizations, journalists have human rights, obligations, and norms. Journalists obey common principles of ethics, including telling the truth and eliminating dangers. Journalists have the social power to frame political agendas and influence public opinion (Wahl-Jorgensen and Hanitzsch 2009). This makes it possible that not all journalists know the code of ethics so that some journalists have not applied the ethical code in TVRI Jakarta, implementing the process of learning by doing, thus enabling a journalist who has not already applied the ethical code to learn and apply the ethical code. (Levine 2017)

The teleological approach is everything that has a specific purpose and the consequences of the coverage itself. Teleology is teaching that defines all things and all events as leading to a specific purpose. Teleology advocates ethical decisions based on consequences and substantiating criteria such as pleasure or happiness. The greatest good for society has meant as a benefit to everyone. Human conduct is aimed at happiness, hence a work of good or bad value, as far as it can increase or diminish happiness as possible. The journalistic hedonist confirms that the truth or the error of action of journalism depends on the pleasure or unpleasure it acquires (Mubarok 2017). How to apply it by remembering what we present will be something that people receive both reading and viewing. If the thing were not to benefit and simply impact society it would be the guideline to avoid producing such journalistic products. Then those actions or actions would have a particular purpose, such as for harmful reporting if that person did not want us to preserve the event, we 
could use, for example, the silent recording that we have kept if it is a danger to us but of great benefit to the public (Lestari 2019). Sources have a teleological approach when there's a source that's hard enough to find or there's news that's very complicated and rather impressive being covered by certain parties that usually cover with the press and we can tell them what's going on. Like when we can't go in to cover somewhere we can take a picture from the outside and we can ask with the security guard up front but we don't take a picture directly into that person. (Erawaty and Irwansyah 2019).

If any of their personnel violated the code of ethics were deliberate or deliberate, they would still try to bring personal caution to the offender, but if the violation persists, then would be completed in the internal TVRI reported to the appropriate leader. Violators must immediately warn that a journalist must thoroughly study and understand the definition and meaning of the ethical code of journalism, whether directly or indirectly, for example by experience in working the field and returning to one's intentions in working, with the intention of worship and kindness that the ethical code of journalism is well implemented. (Jufrizal 2019).

When reporting the news, it needs to focus on the process, because good processes get good results too, but both must also be balanced between process and result. Speaking of a teleological approach, it's beneficial because reporting a news story can never know the process on the ground. A journalist must have an objective attitude, which refers to the objectivity of information and the significance or relevance of the information to society. The media is strongly demanded to present fair, unbiased news. That way the public will get some quality information. (Arum 2018). When reporting the news, it needs to focus on the process, because good processes get good results too, but both must also be balanced between process and result. Speaking of a teleological approach, it's beneficial because reporting a news story can never know the process on the ground. A journalist must have an objective attitude, which refers to the objectivity of information and the significance or relevance of the information to society. The media is strongly demanded to present fair, unbiased news. That way the public will get some quality information. (DíazCampo and Segado-Boj 2015). The results and discussions have concluded that the journalistic code of ethics is strongly followed by journalists in accordance with wiling barus's traditional ethical and work ethic (2010: 235), which is the ethical and work ethic set up and determined by professional organizations to prevent members of the existing professional organization from engaging in practices that endanger professions and society. Freedom of the press is used as a basis for violating the rights of others, hence an ethical code is essential. 


\section{CONCLUSIONS AND SUGGESTION}

The conclusion is that the teleological approach is anything that has a specific purpose and consequences of the reporting effect itself. Teleology is teaching that explains that everything and all events lead to a certain purpose in carrying out their duties. journalists at TVRI Jakarta do a teleological approach but this is of course done by them by applying a journalistic code of ethics to produce journalistic products that are relevant, useful, but not impolite and unethical because the ethics that are upheld in journalistic work are the forerunner of the founding of the industry mass media which is recognized as one of the pillars of democracy and community development.

So the suggestion that we can provide is that for journalists when doing their work, the teleological approach might not be the most humane way to produce journalistic products, this is because the teleological approach is more focused on the result rather than the process. However, journalists can actually use a teleological approach and still be polite in their way of distributing news by completely following the ethical codes of journalism, like the journalist in TVRI Jakarta.

\section{BIBLIOGRAPHY}

Arifin, Zainal, and Emi Puasa Handayani. 2020. "Implementation Pasal 5 Journalistic Code of Ethics ( JCE ) in Covering the Cases of Children with Laws in the Kediri," 21-24.

Arum, Novita. 2018. "PELANGGARAN KODE ETIK JURNALISTIK DALAM MEDIA ONLINE.” UNIVERSITAS SUMATERA UTARA.

Babran, Sedigheh, and Mahbobeh Ataherian. 2019. "Professional Ethics Codes for Global Media." International Journal of Ethics and Society 1 (2): 8-15.

Basri, Hasan. 2014. "Using Qualitative Research in Accounting and Management Studies: Not a New Agenda." Journal of US-China Public Administration 11 (10): 831-38. https://doi.org/10.17265/1548-6591.

Díaz-Campo, Jesús, and Francisco Segado-Boj. 2015. "Journalism Ethics in a Digital Environment: How Journalistic Codes of Ethics Have Been Adapted to the Internet and ICTs in Countries around the World." Telematics and Informatics 32 (4): 735-44. https://doi.org/10.1016/j.tele.2015.03.004.

Erawaty, Dyah Permana, and Nfn Irwansyah. 2019. "Indonesia Journalistic Code of Ethics (News Aggregation Study)." Journal Pekommas 4 (2): 197. https://doi.org/10.30818/jpkm.2019.2040210.

"Ethical Journalism - The New York Times." n.d. Accessed October 15, 2021. https://www.nytimes.com/editorial-standards/ethical-journalism.html\#.

Fitri, and Adeni. 2020. "THE URGENCY OF APPLYING JOURNALISTIC ETHICS IN ONLINE ISLAMIC MEDIA REPORTING ACTIVITIES: A CONCEPTUAL STUDY." Islamic Communication Journal 5 (Januari-Juni): 19-37.

Jufrizal, Jufrizal. 2019. "Implementasi Kode Etik Jurnalistik." SUSTAINABLE: Jurnal Kajian Mutu Pendidikan 2 (1): 128-53. 
https://doi.org/10.32923/kjmp.v2i1.985.

"Kasus Setya Novanto, Metro TV Tak Toleransi Pelanggar Kode Etik - Metro Tempo.Co." n.d. Accessed October 21, 2021. https://metro.tempo.co/read/1034724/kasus-setya-novanto-metro-tv-taktoleransi-pelanggar-kode-etik.

Katz, David L. 2010. "Virtual Mentor (Review)." Ethics 12 (5): 286-92.

Kryukova, Svetlana V, Nadezhda N Khuhryanskaya, Irina V Mikulina, and Yuliya N Shatalova. 2018. "Ethical Aspects of the Journalistic and Advertising Texts' Analysis.” Revista San Gregorio, no. 23: 140-47.

Lestari, Rani Dwi. 2019. "Shifting Journalistic Ethics in the Internet Age, Case Study: Violation of Journalistic Ethics in Journalistic Products and Journalist Behavior in Online Media." Komunikator $11 \quad$ (2). https://doi.org/10.18196/jkm.112027.

Levine, Meredith A. 2017. "Journalism Ethics and the Goldwater Rule in a 'PostTruth' Media World." Journal of the American Academy of Psychiatry and the Law 45 (2): 241-48.

Mubarok. 2017. "Otonomi Individu Jurnalis Dalam Pengambilan Keputusan Etis Peliputan Bencana Pendahuluan.” Mediamorfosa, no. Cetakan Pertama: 24759.

Wahl-Jorgensen, Karin, and Thomas Hanitzsch. 2009. The Handbook of Journalism Studies. New York: Routledge. 